\title{
EX CORDE ECCLESIAE O NATURZE I MISJI UNIWERSYTETU KATOLICKIEGO
}

Jednym z istotnych zagadnień dyskusji na temat przemian we współczesnej, zglobalizowanej kulturze jest refleksja na temat kondycji idei uniwersytetu, instytucji, która w cywilizacji zachodniej od czasów średniowiecza miała swoje stabilne i autonomiczne miejsce. Zagadnienie to dodatkowo wpisuje się w kontekst wdrażania nowych form organizacyjnych i zasad oceny efektów badawczych oraz możliwości ich praktycznego i utylitarnego wykorzystania w nowoczesnych technologiach. Nie bez znaczenia jest proces umasowienia studiów i swoistej uniformizacji szkolnictwa wyższego, tak co do jej struktur, jak i zasad funkcjonowania; jego prawidła wyznacza program Procesu Bolońskiego przyjęty pod koniec ubiegłego stulecia ${ }^{1}$. Przemiany w kulturze o zakresie uniwersalnym i współczesne, niekiedy sprzeczne, oczekiwania wobec uniwersytetów poddawanych wymogom sprawozdawczości, parametryzacji i unifikacji co do działania, skłaniają wielu autorów do formułowania opinii o kryzysie tej instytucji ${ }^{2}$. Z tymi zagadnieniami są konfrontowane także uniwersytety katolickie, które z jednej strony funkcjonują w wielu krajach

* Ks. prof. dr hab., Katolicki Uniwersytet Lubelski Jana Pawła II; e-mail: antoni.debinski@kul.pl, https://orcid.org/0000-0003-0777-7448.

1 B. Reinalda, E. Kulesza, The Bologna Process. Harmonizing Europe's Higher Education: Including the Essential Original Texts, Leverkusen-Opladen 2006, s. 3-18.

2 Literatura na ten temat jest obfita; nowszą ostatnio zestawiają autorzy artykułów zamieszczonych w kwartalniku Ethos 2009, z. 1/2(85/86), który został opatrzony podtytułem: „Koniec misji uniwersytetu?". Podobnie problematyce tej został poświęcony Znak 2000, nr 2 (537), zaopatrzony podtytułem: „Uniwersytet przed reanimacją” i Znak 2015, nr 11 (726) zaopatrzony podtytułem: „Uniwersytety katolickie do lamusa?”; zob. także R. Scruton, Koniec uniwersytetu, tłum. D. Chabrajska, Ethos 2015, z. 1(109), s. 53-63. 
w ramach różnych systemów edukacji i szkolnictwa wyższego, z drugiej w obliczu procesu laicyzacji społeczeństw dążą do zachowania swojej tożsamości i realizowania właściwej im misji³.

Przedmiotem niniejszych rozważań jest specyfika uniwersytetu katolickiego. Po przedstawieniu krótkiego wprowadzenia historycznego odnośnie do samej idei uniwersytetu (1), naszkicowaniu podstawowych trendów mających wpływ na jego funkcjonowanie (2), chciałbym podjąć kwestie przymiotnikowości i statusu prawnego uniwersytetu katolickiego (3), jego natury (4) oraz misji (5).

\section{Idea i początki uniwersytetu}

W pewnym uproszczeniu można uznać, że uniwersytet jako instytucja społeczna wyłonił się niemal tysiąc lat temu - aby posłużyć się słowami Konstytucji Apostolskiej Jana Pawła II - Ex corde Ecclesiae (z serca Kościoła). Jest oryginalnym tworem chrześcijańskiej kultury średniowiecza, nie tak mrocznego, spetryfikowanego i zacofanego, jak to chciał w uproszczony i schematyczny sposób przestawiać - powielany aż do dnia dzisiejszego - postoświeceniowy mit. Uniwersytet był jednym z najwspanialszych osiągnięć kultury umysłowej „wieków średnich”, osiągnięć, których roli w cywilizacyjnym rozwoju Europy nie sposób przecenić, bez których „postęp wiedzy i rozwój intelektualny całych społeczeństw byłby praktycznie niemożliwy"4. Jego znaczenie było ogromne we wszystkich obszarach życia; w rezultacie przemożny wpływ tej instytucji w średniowieczu doprowadził do wytworzenia teorii o studium ${ }^{5}$ jako trzeciej - obok kapłaństwa

3 Na temat rozważań dotyczących pojęcia "misji” uniwersytetów zob. J.C. Scott, The Mission of the University: Medieval to Postmodern Transformations, The Journal of Higher Education 2006, t. 77, nr 1, s. 1-39.

4 J. Sondel, Zawsze wierny. Uniwersytet Jagielloński a Kościót rzymskokatolicki, Kraków 2006, s. 13.

5 Wieloznaczny łaciński termin studium oznacza m.in.: badanie, nauka, wykształcenie, zajęcia szkolne, studia, szkoła, zakład naukowy, akademia, uniwersytet; zob. J. Sondel, s.v. Studium, w: tenże, Słownik łacińsko-polski dla prawników i historyków, Kraków 2005, s. 905. Pierwsze uniwersytety były określane mianem studium generale - należały do nich średniowieczne szkoły, do których studenci przybywali z różnych części Europy. Wyróżniały się wysokim poziomem nauczania, przez co zaczęły znacznie wyprzedzać 
(sacerdotium) i cesarstwa (imperium) - władzy o uniwersalnym charakterze w chrześcijańskiej Europie ${ }^{6}$. Dzięki uniwersytetom „kultura zachodnia uzyskała dyscyplinę umysłową i naukową, od której zależne były późniejsze osiągnięcia"7. Istotnie, stały się one potężnym motorem rozwoju cywilizacji.

Średniowieczna universitas ${ }^{8} \mathrm{u}$ swoich początków stanowiła miejsce nauczania wszystkich ówczesnych nauk, była pojmowana jako universitas litterarum, a więc powszechność i wszechstronność studiów. Z drugiej strony zaś, i przede wszystkim, była utworzoną na wzór związku cechowego korporacją, nauczających i uczących się, wspólnotą nauczycieli i studentów - universitas scholarum et magistrorum - zespolonych wspólnym celem poznawania i zgłębiania wiedzy. Studenci i profesorowie bazując na zasadach samorządowych, łączyli się w "grupy interesów", aby realizować wspólne cele i zadania, artykułowali swoje dążenia tak wobec władz państwowych, jak kościelnych ${ }^{9}$. Jednym z ważnych czynników jednoczących ową wspólnotę, dla odróżnienia od innych grup i cechów zawodowych nazywającą się „stanem akademickim”, był ten sam język - łacina, która w okresie wielu stuleci znalazła zastosowanie nie tylko w dyplomacji, komunikacji międzynarodowej, liturgii i Kościele, ale także w szeroko pojętej kulturze. Była ona, jak napisał węgierski pisarz i publicysta Sándor Márai, klamrą spinającą europejską kulturę w duchową jedność ${ }^{10}$.

Należy przy tym pamiętać, że początki uniwersytetu, stanowiącego instytucjonalny wzór pracy naukowej, były zjawiskiem oryginalnie

lokalne szkoły (studium particulare). Nazwa studium generale używana była w odniesieniu do ośrodków, które współcześnie uważamy za pierwsze uniwersytety. Zob. O. Pedersen, The First Universities. Studium Generale and the Origins of University Education in Europe, Cambridge 2000, s. 131-133.

6 H. Rashdall, The Universities of Europe in the Middle Ages, Oxford 1895, s. 4-5; zob. J. Baszkiewicz, Młodość uniwersytetów, Warszawa 1997, s. 7.

7 C. Dawson, Religia i powstanie kultury zachodniej, tłum. S. Ławicki, Warszawa 1959, s. 249.

8 Termin universitas oznacza ogół, powszechność, wspólność, całokształt, całość, ale także związek, stowarzyszenie, korporację; zob. M. Jońca, s.v. Universitas, w: Leksykon tradycji rzymskiego prawa prywatnego. Podstawowe pojęcia, red. A. Dębiński, M. Jońca, Warszawa 2016, s. 376; J. Sondel, s.v. Universitas, w: tenże, Stownik łacińsko-polski..., s. 968.

9 Średniowieczne uniwersytety postrzegano jako wspólnoty korporacyjne (Bolonia) lub jedną wspólnotę, podporządkowaną miejscowemu biskupowi (Paryż); zob. R.S. Rait, Life in the Medieval University, Cambridge 1912, s. 2-11.

10 S. Márai, Dziennik (fragmenty), tłum. i oprac. T. Worowska, Warszawa 2008, s. 37. 
i zadziwiająco europejskim, ściśle związanym z cywilizacją zachodnią, zwaną także okcydentalną, łacińską czy euroatlantycką ${ }^{11}$. Nie wywodziły się bowiem - rozpatrując ich genezę tak z punktu widzenia struktury, sposobu organizacji i celów działania - z tradycji szkół starożytnych założonych na terenie Bliskiego Wschodu, Indii, Chin, Grecji czy Bizancjum. Ich geneza związana była z rozwojem europejskiej kultury średniowiecza; uniwersytet zorganizowany oryginalnie, bez odwoływania się do wcześniejszych wzorców, w profesjonalne fakultety, $\mathrm{z}$ mechanizmem ustanowienia programów nauczania i egzaminów, nadawania stopni akademickich i formalnych dyplomów, z odrębnym ceremoniałem i strojami, był znakomicie wkomponowany w życie oraz pejzaż ówczesnych miast i stanowił kolejną fazę ich rozwoju. Pierwszy uniwersytet w Bolonii, który stał się wzorcem dla innych, powstał pod koniec XI stulecia jako rezultat potrzeb życia publicznego, rozkwitającego handlu i rzemiosła średniowiecznej, zamożnej północnowłoskiej komuny miejskiej oraz dążeń intelektualnych dojrzewających społeczności wyrażających swoje aspiracje intelektualne w języku - z jednej strony - doktryny Kościoła, a z drugiej - tradycji nauki antyku, w tym prawa rzymskiego wprzęgniętego w obsługę stosunków gospodarczych ${ }^{12}$. Był on, jak i kolejne stworzone w XII stuleciu, przykładem swoistej rewolucji intelektualnej i organizacyjnej.

W okresie powstawania pierwszych uniwersytetów przymiotnik „,katolicki" był zgoła niepotrzebny. Co do swojego ideowego charakteru, pełniące funkcje międzynarodowych centrów życia naukowego i kulturalnego, uniwersytety średniowieczne z gruntu były uczelniami katolickimi; zakładał je Kościół, albo też dawał przyzwolenie na ich powstanie $^{13}$. Ich "katolickość” nie musiała być manifestowana w nazwie. Tak było w Europie, począwszy od Bolonii, Paryża, Padwy, Oxfordu, Salamanki, Pragi czy Krakowa. Ciesząc się autonomią, miały także wyłączne

11 Zob. Ch.H. Haskins, The Renaissance of the Twelfth Century, Cambridge 1971, s. 368-396 (wraz z wykazem literatury, s. 397). Literatura na temat historii uniwersytetów średniowiecznych jest obfita, jednak status pracy podstawowej zachowuje wielokrotnie wydawane opracowanie: R. Hastings, The Universities of Europe in the Middle Ages, t. 1-2, Cambridge 2010.

12 J. Verger, The Birth of the Universities, w: A History of the University in Europe, t. 1. Universities in the Middle Ages, red. H. de Ridder-Symoens, Cambridge 1992, s. 47-55.

13 Do XV w. włącznie uniwersytety były instytucjami papieskimi; zob. S. Kunowski, Rola uniwersytetów katolickich w historii nauki i oświaty, Zeszyty Naukowe KUL 1968, t. 11, z. 3/4, s. 34; S. Swieżawski, Kultura umystowa wieków średnich, Lublin 1949, s. 20. 
prawo nadawania absolwentom prawa do nauczania we wszystkich uniwersytetach (licentia docendi ubique terrarum) i nadawania stopni naukowych respektowanych w całym świecie chrześcijańskim. Stworzona przez Anzelma z Canterbury (1033-1109) formuła fides quaerens intellectum (wiara poszukująca rozumowego wyjaśnienia) stanowiła od początków dewizę i opis sensu ich istnienia. Co do zasady takimi pozostały $\mathrm{w}$ swoich strukturach, metodach z zakresu badań naukowych oraz nauczania aż do XVI w., tj. do rozłamu w Kościele spowodowanego przez reformację zapoczątkowaną przez Marcina Lutra (1483-1546) ${ }^{14}$. Po rewolucji francuskiej nasilił się proces upaństwowienia i sekularyzacji uniwersytetów europejskich, który korespondował z postępującą specjalizacją, będącą w dużej mierze efektem rozwoju dyscyplin szczegółowych oraz zerwania z modelem kształcenia integralnego ${ }^{15}$.

Uniwersytet okazał się być instytucją długiego trwania (fr. longue durée); niezależnie od tego, że zmieniały się systemy i formacje polityczne, upadały dynastie i państwa, w zapomnienie odchodziły partie polityczne i organizacje międzynarodowe, uniwersytet jako instytucja trwa do dnia dzisiejszego. Interesującym zadaniem badawczym byłoby prześledzenie pojawiania się przy terminie "uniwersytet” przymiotników innych niż nawiązujących do fundatorów czy lokalizacji. Przez niemal tysiąc lat uniwersytety podlegały wpływom państwa i społeczeństwa. Poddawano je reformom, tak że mówi się obecnie o typach uniwersytetów, nawiązujących do twórców nowoczesnych uniwersytetów w XIX w., np. humboldtowskim, napoleońskim, newtonowskim. Wyróżnianie typów zależy oczywiście od przyjętych kryteriów. Dzieli się je także na uniwersytety badawcze i zawodowe albo na uniwersytety i uniwersytety przymiotnikowe, a wśród tych ostatnich, np. przyrodnicze, medyczne, techniczne, humanistyczne, a nawet przyrodniczo-humanistyczne czy też humanistyczno-przyrodnicze. Rozróżnienia te idą paralelnie do procesu tworzenia list dyscyplin naukowych i przemian w zakresie metodologii badań. Owe podziały są regulowane ustawowo w zależności od określonego porządku prawnego.

$14 \mathrm{Na}$ temat wpływu zmian religijnych i politycznych na funkcjonowanie uniwersytetu zob. N. Hammerstein, Relations with Authority, w: A History of the University in Europe, t. 2. Universities in Early Modern Europe (1500-1800), red. H. de Ridder-Symoens, Cambridge 1997, s. 115 [114-153].

$15 \mathrm{Na}$ temat zmian, jakie zaszły w organizacji i postrzeganiu misji uniwersytetów w XVIII w., zob. H.C. Barnard, Education and French Revolution, Cambridge 1969. 
Do grupy uczelni przymiotnikowych należą uniwersytety katolickie. Proces ich powoływania nasilił się od drugiej połowy XIX w., co było związane z działalnością papieża Leona XIII. W swoim nauczaniu postulował obecność (czy powrót) chrześcijaństwa we wszystkich obszarach życia, a zwłaszcza na polu społecznym, naukowym i kulturalnym. Ważnym narzędziem miały stać się uniwersytety katolickie. Tworzone, reaktywowane lub aprobowane przez Kościól, nawiązywały i miały w jakimś zakresie zastąpić dawne, powstałe $\mathrm{w}$ średniowieczu uniwersytety ściśle związane z kulturą chrześcijańską ${ }^{16}$. Kolejne bodźce pochodziły od papieża Piusa X, który na początku XX w. odwoływał się do zawołania: Omnia instaurare in Christo - „Wszystko odnowić w Chrystusie”. Aby omówić rolę i zadania uniwersytetów katolickich, należy opisać, chociażby skrótowo, otoczenie społeczne, w jakich one współcześnie funkcjonują.

\section{Kluczowe trendy współczesności}

Dla uniknięcia nieporozumień należy wyjaśnić termin „kluczowe” innymi słowy podstawowe i najważniejsze - obecny w tytule paragrafu. Chodzi oczywiście o te trendy i tendencje w życiu społecznym, które mają wpływ na kształt uniwersytetu, zarówno na jego organizację jako instytucji społecznej, jak i na programy nauczania oraz liczbę i rodzaj studentów oraz kadry. Nie roszczę też sobie pretensji do wyliczenia wszystkich tego typu tendencji, a jedynie tych, które pozwolą sformułować argumenty na rzecz roli, którą chcę przypisać uniwersytetowi katolickiemu.

Pierwszym trendem, już wzmiankowanym, jest niewątpliwie globalizacja. W ujęciu podręcznikowym globalizacja to zbiór procesów w wymiarze światowym o charakterze ekonomicznym, politycznym i kulturowym powodujących wzrost zakresu i intensyfikacji różnych relacji społecznych, wpływów, oddziaływań oraz sieci powiązań i współzależności, a zachodzących między państwami, społeczeństwami, gospodarkami narodowymi, co skutkuje tworzeniem się coraz większego ujednolicania świata, powstawaniem przejawów tzw. „światowego społeczeństwa” (paralelnie do zanikania kategorii państwa narodowego), wzrostem

16 B.M. Mezei, Kryzys uniwersytetu. O roli katolickich instytucji ksztatcenia wyższego, tłum. D. Chabrajska, Ethos 2009, z. 1/2(85/86), s. 44-46. 
znaczenia korporacji transnarodowych, międzynarodowych organizacji finansowych oraz powstawaniem tzw. zjawiska kompresji czasu i przestrzeni, spowodowanego m.in. faktem wykorzystywania nowych środków do komunikacji międzyludzkiej ${ }^{17}$.

Nie wnikając w dyskusje na temat istoty i konsekwencji globalizacji, podkreślmy, że ma ona wiele wymiarów, m.in. polityczny, kulturowy, społeczny i ekonomiczny, a każdy z nich wywiera wpływ na kształt uniwersytetu i kształcenie wyższe. Dwie konsekwencje wydają się być oczywiste. Po pierwsze, studenci i wykładowcy są z różnych krajów globu, co wnosi w świat akademicki wieloaspektową różnorodność, a w życiu codziennym bodaj najistotniejszy jest aspekt kulturowy. Do internacjonalizacji studiów uniwersytety są zresztą zachęcane przez władze polityczne za pomocą różnych mechanizmów. Po drugie, globalizacja powoduje zwiększanie nacisku na konkurencyjność nie tylko firm, ale i państw na rynku globalnym, co znajduje swe odzwierciedlenie w polityce edukacyjnej, m.in. przez wspieranie tych obszarów badań i nauczania, które mają znaczenie ekonomiczne oraz traktowanie uniwersytetów jako "gracza na rynku”. Uniwersytety i szkoły wyższe są zachęcane do uczestniczenia w rankingach światowych.

Drugi trend to pluralizm wartości, a ostatecznie zindywidualizowany relatywizm: nikt i nic nie powinno wskazywać jednostce, co jest dobre i złe w sensie moralnym, a racjonalna dyskusja może dotyczyć jedynie tego, co jednostka uważa za moralnie dobre czy złe. Zygmund Bauman, znany w świecie teoretyk i komentator ponowoczesności lub „płynnej nowoczesności" przyjmuje za fakt kres etyki kodeksowej, sferę moralną postrzega jako $\mathrm{z}$ istoty przedracjonalną i zindywidualizowaną. $\mathrm{W}$ takim ujęciu jednostka ze swoim wyborem moralnym musi zmagać się sama, pozbawiona oparcia w instytucjach i normach, które stały się "płynne". W rezultacie niepoddana regulacji jednostkowa wola stanowi dziś główną

17 Zob. M. Kempny, s.v. Globalizacja, w: Encyklopedia socjologii, t. 1, red. Z. Bokszański i in., Warszawa 1998, s. 241; E. Wnuk-Lipiński, Świat międzyepoki. Globalizacja, demokracja, państwo narodowe, Kraków 2004, s. 23 i nn.; P. Sztompka, Socjologia zmian społecznych, tłum. J. Konieczny, Kraków 2005, s. 93 i nn.; U. Beck, What Is Globalization?, Cambridge 2000, s. 23 i nn.; K. Gilarek, Państwo narodowe a globalizacja - dynamika powstawania nowego ładu, Torun 2004, s. 56 i nn.; A. Dylus, Globalizacja. Refleksje etyczne, Wrocław 2005, s. 12 i nast. Na temat niektórych aspektów procesu globalizacji z punktu widzenia nauczania Kościoła zob. J.W. Gałkowski, D. Stanny, Globalizacja w nauczaniu Jana Pawła II, Ethos 2011, z. 4(96), s. $70-80$. 
instancję wyborów moralnych ${ }^{18}$. Tolerancja urasta wobec tego do rangi jedynej wspólnej wartości. Oczywiście, w praktyce nie jest to takie proste i niezależnie od deklarowanej tolerancji uważa się, że pewne czyny są obiektywnie złe, nawet jeśli w jakiejś kulturze są one akceptowane. Niemniej trend ten wpływa na rozumienie edukacyjnych funkcji uniwersytetu, bowiem funkcja wychowawcza co najmniej schodzi na dalszy plan. Rolę wykładowcy dobrze wobec tego charakteryzują słowa Maxa Webera sprzed stu lat: „,sprzedaje mi on swoją wiedzę i metody za pieniądze mojego ojca, tak samo jak straganiarka sprzedaje kapustę mojej matce"19.

Przywoływane wyżej słowa niemieckiego socjologa, filozofa, prawnika i ekonomisty kreślącego swoje wizje nowoczesnego społeczeństwa kapitalistycznego oraz wpisującego w nie swoją nowoczesną koncepcję różnych zawodów, wskazują kolejną tendencję - urynkowienie ${ }^{20}$. Oznacza to co najmniej tyle, że relacje rynkowe stają się podstawą większości - jeśli nie wszystkich - innych relacji, $\mathrm{w}$ tym także relacji w świecie akademickim $^{21}$. Wykładowca to nie mistrz, ale usługodawca (czy też provider usług edukacyjnych); badacz to „umysł do wynajęcia”; student to usługobiorca, z którym uczelnia podpisuje umowę na określoną liczbę godzin każdych zajęć i zobowiązuje się do nauczenia określonych rzeczy; akademik to nie badacz i wychowawca młodego pokolenia badaczy, ale „robotnik naukowy”, który pod groźbą oceny negatywnej musi dostarczyć uczelni określoną liczbę punktów za publikacje i zdobyte granty; rektor (czy inni "funkcyjni”) to nie „pierwszy między równymi”, ale manager, który ma zagwarantować efektywność badań i nauczania. Krytyka przekształcania uniwersytetu w element rynku jest dobrze znana, tak jak i wezwania do rewolucji przeciw kolonizacji uniwersytetów przez managerów, którzy, przy pomocy strachu (zwolnienie), systemu motywacyjnego (pieniądze i awanse) oraz wprowadzenie zasady konkurencyjności między akademikami, wymuszają skuteczność i efektywność pracy naukowej

18 Z. Bauman, Etyka ponowoczesna, Warszawa 2012.

19 M. Weber, Nauka jako zawód i powołanie, w: M. Weber, Polityka jako zawód i powołanie. Wybór pism, wstęp i oprac. Z. Krasnodębski, tłum. P. Dybel, Warszawa 1998, s. 213.

${ }^{20}$ O tym aspekcie funkcjonowania uniwersytetu zob. A. Lekka-Kowalik, Uniwersytet na rynku ustug edukacyjnych - szansa czy klęska?, Ethos 2009, z. 1/2 (85/86), s. 52-69.

21 Piotr Nowak napisał z sarkazmem: „Pod naporem chwili obecny dzisiejszy Uniwersytet usuwa się w niebyt, staje się karykaturą Uniwersytetu. Jego program pisze rynek potrzeb, a więc człowiek masowy, nie człowiek wolny; biuralista, nie naukowiec", tenże, Hodowanie troglodytów, Warszawa 2014, s. 8. 
i wykładowej. Oczywiście owa skuteczność i ekonomiczność są również rozumiane rynkowo: rezultaty badań muszą być komercjalizowalne (innymi słowy: dadzą się sprzedać za konkretne pieniądze tu i teraz), podobnie jak oferta zajęć ma przyciągnąć studentów, za którymi idą pieniądze (w formie dotacji/subwencji ministerialnej czy czesnego), a zdobyte punkty zapewniać wysokie miejsce $w$ rankingach. Owo zjawisko zwane jest komodytyzacją wiedzy, a jej „pedagogicznym odpowiednikiem, wedle celnego określenia amerykańskiego filozofa i socjologa Steva Fullera jest "curriculizacja” programów nauczania ${ }^{22}$. Prawa rynkowe obowiązują oczywiście nie tylko $\mathrm{w}$ ramach jednej instytucji, ale też $\mathrm{w}$ całym świecie akademickim ${ }^{23}$. Inne uniwersytety są "konkurentami”, ubiegającymi się o ten sam rynek grantów, zleceń i kandydatów na studia.

Czwarty trend to budowanie społeczeństwa wiedzy. Tworzymy - także przy pomocy środków politycznych - społeczeństwo wiedzy. Ciągle dyskutuje się nad cechami charakterystycznymi tego społeczeństwa. Bodaj wszyscy zgadzają się co do tego, że wiedza jest kluczowym źródłem innowacji, a przez to - rozwoju społeczno-gospodarczego. W pewnym sensie nie jest to idea rewolucyjna - ludzkie działanie jako działanie racjonalne zawsze jest oparte na twierdzeniach dotyczących rzeczywistości. Rewolucyjne jest natomiast rozumienie wiedzy. Wiedza to nie prawdziwe i uzasadnione przekonania, jak ją definiowano $\mathrm{w}$ tradycyjnej epistemologii, ale capacity to act - zdolność czy też możliwość działania. Nie chodzi o zaspokojenie poznawczych potrzeb człowieka, który - jak twierdził Arystoteles - ze swej natury chce wiedzieć, ale o funkcję wiedzy $\mathrm{w}$ tworzeniu produktów zaspokajających rynkowo zdefiniowane potrzeby $^{24}$. Nie chodzi już - jak to chciał Francis Bacon - o polepszenie losu

22 Zob. S. Fuller, On Commodification and the Progress of Knowledge in Society. A Defence, Spontaneous Generations. A Journal for the History and Philosophy of Science 2013, t. 7, nr 1, s. 6-14.

23 Konstatację na temat konieczności stawiania pytań humanistom o produkt, jaki mogą zaoferować/sprzedać, przedstawił T. Węcławski na przykładzie teologów; zob. tenże, Uniwersytet i wyzwania fundamentalne, Znak 2000, nr 2 (537), s. 66-67.

${ }_{24}$ Zob. A. Lekka-Kowalik, Komodytyzacja prawdy - komodytyzacja nauki-komodytyzacja człowieka. Chrześcijańska odpowiedź, w: Ekonomia a chrześcijaństwo. Świat biznesu przez pryzmat encyklik św. Jana Pawła II Centesimus annus i Laborem exercens, red. A. Lekka-Kowalik, Warszawa 2017, s. 193-205. 
ludzkości ${ }^{25}$, ale o innowacje, które mogą stać się towarem tu i teraz oraz zapewnić przewagę konkurencyjną. O konieczności bardzo wyraźnego rozróżniania informacji i wiedzy, a także następnej kategorii - mądrości, znakomicie przypominają słowa angielskiego poety i myśliciela, laureata Nagrody Nobla, Thomasa S. Eliota, który pytał: „Gdzie się podziała nasza mądrość, którą zastąpiła wiedza, gdzie się podziała nasza wiedza, którą zastąpiła informacja" 26 .

Rola nauki w społeczeństwie wiedzy ma dwie ważne konsekwencje: umasowienie edukacji oraz konieczność konkurowania uniwersytetu z innymi instytucjami edukacyjnymi. Wzrost liczby studentów, a w dalszej kolejności posiadaczy stopni zawodowych i naukowych, jest faktem niepodlegającym dyskusji. Konsekwencje tych procesów też są dobrze znane: utyskiwanie na spadek jakości nauczania, poziomu studentów, strywializowanie wykładów itp. pojawia się bodaj w każdej publikacji poświęconej tematyce umasowienia nauczania. W społeczeństwie wiedzy uniwersytety przestały też mieć monopol na wiedzę. Pojawiło się wiele innych instytucji edukacyjnych i badawczych, które szybciej oferują wycinek wiedzy potrzebny do zdobycia przewagi konkurencyjnej na rynku pracy, czy też przyjmują zlecenia na szybkie rozwiązanie bieżących problemów rozmaitych podmiotów gospodarczych, politycznych itd. Odpowiedź na pytanie o to, jak utrzymać się na "rynku wiedzy” stało się istotnym elementem strategii rozwoju, którą uniwersytety opracowują na wzór współczesnej korporacji, niekiedy zamiast misji! Oczywiście, uniwersytety zawsze kształciły również fachowców, ale ich pierwszym zadaniem było wyposażenie studentów w wiedzę ogólną, syntetyczną, na najwyższym możliwym poziomie. Obecnie to się zmienia - kształceni są głównie wąsko wyspecjalizowani fachowcy. José Ortega y Gasset na ich określenie używa terminu „współcześni barbarzyńcy”27, którzy według jego opinii

25 A. Lekka-Kowalik, Nauka i Dobro człowieka [online], serwis internetowy Sapiencjokracja - gdzie rządzi mądrość, http://sapiencjokracja.pl/nauka-i-dobro-czlowieka/ [dostęp: 22.01.2020 r.].

26 T.S. Eliot, Chóry z „Opoki”, tłum. M. Sprusiński, Więź 1976, z. 12 (224), s. 86.

27 Według J. Ortega y Gasset prototypem człowieka masowego jest człowiek nauki. Praca naukowa staje się coraz bardziej specjalistyczna. Współczesny naukowiec to specjalista znający pewien wąski fragment wiedzy, nie jest człowiekiem mądrym, ale ignorantem we wszystkich innych dziedzinach; zob. tenże, Bunt mas, tłum. P. Niklewicz, Zakrzewo 2016. Komentując skutki rozwoju naukowo-technicznego, S. Kamiński pisze: „Rozwój nauki i techniki wyprzedził w znacznym stopniu rozwój potrzebnej człowiekowi 
myślą schematami i używają w swoim zawodzie fachowego żargonu. Ich przygotowanie, jak przekonuje hiszpański filozof i eseista, stało się nadrzędnym i głównym zadaniem współczesnych uniwersytetów.

Wszystkim tym trendom towarzyszy oczywiście gwałtowny rozwój naukowo-techniczny i to, co kiedyś należało do science fiction, dziś jest projektem badawczym. Czy w takim świecie kategoria „uniwersytet katolicki" ma jeszcze jakiś sens? Czy uniwersytet katolicki pełni w tym świecie jakoś wyróżnioną funkcję? By odpowiedzieć na to pytanie, należy najpierw zapytać o formalne cechy uniwersytetu katolickiego.

\section{Katolicki - czyli jaki?}

W czasach współczesnych tożsamość oraz sposób postrzegania uniwersytetu katolickiego opisywane są poprzez wskazanie dwu elementów: „uniwersyteckość” i „katolickość”. Zestawienie tych terminów nasuwa pytanie, jaka jest relacja pomiędzy rzeczownikiem „uniwersytet” i przymiotnikiem „katolicki”, czy aby jedno nie jest w opozycji lub nie przysłania drugiego ${ }^{28}$ To złożenie terminów nakazuje rozważyć ich wzajemne odniesienie, tym bardziej że zgodnie z obecnie obowiązującą ustawą o szkolnictwie wyższym tylko niektóre szkoły wyższe - spełniające wymogi ustawowe ${ }^{29}$ - mogą posługiwać się bezprzymiotnikową nazwą

duchowości, tak że często staje się karykaturą samego siebie. [...] Społeczeństwo zaś zbyt często i natarczywie pyta o to, jak nauka może uczynić nas silniejszymi i bogatymi, a za rzadko i bez przekonania, jak nauka mogłaby uczynić nas mądrymi i dobrymi", tenże, Nauka i Metoda. Pojęcie nauki i klasyfikacja nauk, red. A. Bronk, Lublin 1992, s. 237.

28 Stefan Sawicki postuluje, ,,aby o charakterze tych uniwersytetów informował w ich nazwie nie przymiotnik katolicki a nazwisko patrona: św. Tomasza z Akwinu, Jana Pawła II czy Cypriana Norwida”. Jak uzasadnia: „Ważne jest, sądzę, aby w samej nazwie uczelni «katolickość» nie przysłaniała «uniwersytetu». Uniwersytet jest najważniejszy", tenże, O uniwersytecie katolickim - dziś. Rozmowa z prof. Stefanem Sawickim, wieloletnim prorektorem KUL, Ethos 2009, z. 1/2 (85/86), s. 241.

29 Zgodnie z art. 1 (obecnie uchylonej) ustawy z dnia 27 lipca 2005 r. - Prawo o szkolnictwie wyższym (Dz. U. z 2005 r. Nr 164, poz. 1365): „Wyraz «uniwersytet» może być używany w nazwie uczelni, której jednostki organizacyjne posiadają uprawnienia do nadawania stopnia naukowego doktora co najmniej w dwunastu dyscyplinach, w tym przynajmniej po dwa uprawnienia $\mathrm{w}$ dziedzinach nauk humanistycznych, społecznych lub teologicznych, matematycznych, fizycznych lub technicznych, przyrodniczych oraz 
„uniwersytet”, a przymiotniki uzupełniające nazwę uniwersytetu wskazują jego specyficzny profil ${ }^{30}$.

Stanowczo należy odejść, przede wszystkim odrzucając ideologiczne uprzedzenia, od kierunku interpretacji zakładającej spięcie czy przeciwstawienie pomiędzy tymi pojęciami. Przede wszystkim dlatego, że, jak to wyraził Jan Paweł II w przemówieniu w Louvain-la- Neuve, „sama historia odrzuciła to uproszczone twierdzenie" ${ }^{\prime \prime}$. Nie można bowiem poważnie twierdzić - powiedział papież - że pierwsze uniwersytety w Europie (Bolonia, Paryż, Salamanka, Kraków), które utworzył Kościół i „nadał im życiową energię", ${ }^{32}$ nie były prawdziwymi uniwersytetami. Prócz tego, historycznego, można jeszcze przytoczyć inny, semantyczny argument. Otóż łacińskie wyrażenie universitas studiorum oznacza całość, wspólność, ogół, wszechstronność studiów. Zaś wywodzący się z języka greckiego termin catholicus również oznacza powszechny, całościowy. Zatem przymiotnik "katolicki” dookreśla jako całościowe to, co ze swej natury już jest uniwersalne lub winno takim być. Innymi słowy katolickość oznacza wzmocnienie uniwersalności uniwersytetu, a z kolei jego uniwersyteckość winna potęgować katolickość ${ }^{33}$.

Zatem czym jest uniwersytet katolicki, jaka jest cecha odróżniająca go od innych szkół wyższych, innych uczelni? Z formalnego punktu widzenia owa odrębność jest nader oczywista, wynika z uregulowań prawnych; ustawodawca kościelny precyzyjnie określa, jaka szkoła wyższa może

prawnych lub ekonomicznych". Z kolei według art. 16 ust. 3 obowiązującej ustawy z dnia 20 lipca 2018 r. - Prawo o szkolnictwie wyższym i nauce (tekst jednolity: Dz. U. z 2020 r. poz. 85 z późn. zm.): „Wyraz «uniwersytet» jest zastrzeżony dla nazwy uczelni akademickiej posiadającej kategorię naukową A+, A albo B+ w co najmniej 6 dyscyplinach naukowych lub artystycznych, zwanych dalej «dyscyplinami», zawierających się w co najmniej 3 dziedzinach nauki lub sztuki, zwanych dalej «dziedzinami»".

30 Art. 3 ust. 2-3 ustawy - Prawo o szkolnictwie wyższym.

31 Jan Paweł II, O powołaniu uniwersytetu katolickiego. Przemówienie na Uniwersytecie Katolickim Louvain-la-Neuve, 21 maja 1985 r., w: tenże, Wiara i kultura: dokumenty, przemówienia, homilie, wybór tekstów i oprac. red. M. Radwan, T. Gorzkula, K. Cywińska, Rzym-Lublin 1988, s. 296-297.

32 Tamże.

33 Szerzej zob. Z. Grocholewski, Rola uniwersytetów katolickich na terenach wyniszczonych przez komunizm, Ethos 2009, z. 1/2 (85/86), s. 91; P. Mazurkiewicz, Uniwersytet „z przymiotnikiem", Znak 2005, nr 11 (6066), s. 86; literatura na temat uniwersytetów katolickich jest stosunkowo obfita, nowszą zestawił E.K. Sakowicz, Uniwersytet katolicki. Teksty bibliografia - dokumenty, Lublin 2012. 
być kwalifikowana i nazywana jako „katolicka”, kto i pod jakimi warunkami może powołać ją do istnienia i jakie wymogi winna spełniać34. Kodeks Prawa Kanonicznego promulgowany przez Jana Pawła II w 1983 r. potwierdzając w kan. 807 prawo Kościoła do zakładania uniwersytetów katolickich i kierowania nimi, określił jednocześnie ich cele. Działalność uniwersytetów winna być podporządkowana, czytamy w kodeksie, "pogłębianiu kultury ludzi”, ,pełniejszemu rozwojowi osoby ludzkiej”, a także „wypełnianiu posługi nauczania” 35 .

Z punktu widzenia prawa kanonicznego obok uniwersytetów katolickich należy wyróżnić inne kategorie uczelni wyższych, uniwersytety i wydziały kościelne (zwane niekiedy papieskimi), które funkcjonują samodzielnie lub w ramach innych struktur ${ }^{36}$. Nie wdając się w szczegółowe rozważania, można stwierdzić, że działalność uniwersytetów i wydziałów kościelnych skupia się przede wszystkim na studium nauk kościelnych i nauk z nimi związanych; ich zasadniczym celem jest przygotowanie do pełnienia posług kościelnych, a nadawane przez nie stopnie powagą

34 Przepisy dotyczące uniwersytetów katolickich zostały zawarte w kan. 807-814 Kodeksu Prawa Kanonicznego z 1983 r. (w odniesieniu do uniwersytetów i instytutów kościelnych w kan. 815-821); Kodeks Katolickich Kościołów Wschodnich przepisy te zawiera w kan. 640-645. Na temat prawnych uregulowań w prawie kanonicznym odnośnie do uniwersytetów katolickich zob. H. Misztal, Uniwersytet katolicki w doktrynie Kościoła i prawie kanonicznym, w: Ius et lex. Księga jubileuszowa ku czci Profesora Adama Strzembosza, red. A. Dębiński, A. Grześkowiak, K. Wiak, Lublin 2002, s. 425-445 (wraz z wykazaną literaturą); Codex Iuris Canonici. Kodeks Prawa Kanonicznego. Komentarz, red. P. Majer, Kraków 2011, s. 619-623.

35 W kan. 807 jest mowa o prawie zakładania uniwersytetów katolickich przez władzę kościelną, ale brak określenia zakresu tej władzy. Nie ma również precyzyjnych uregulowań, jeśli chodzi o władzę powoływania profesorów oraz pozbawiania ich funkcji w wypadku braku „odpowiednich kwalifikacji naukowych i pedagogicznych, czy mankamentów dotyczących wymaganej nieskazitelnością doktryny i dobrych obyczajów”. Lepiej określone są kompetencje Konferencji Biskupów - do „czuwania”, aby na uniwersytetach katolickich przestrzegano „zasad doktryny chrześcijańskiej” (kan. 810 § 2).

${ }^{36} \mathrm{Na}$ owe zróżnicowanie wskazuje także rozdzielenie uregulowań w prawie kanonicznym - otóż status i działanie uniwersytetów katolickich zostały uregulowane w Kodeksie Prawa Kanonicznego w rozdziale II (Księga III, tytuł III) zatytułowanym: „Uniwersytety katolickie oraz inne instytuty studiów wyższych” oraz w Konstytucji Apostolskiej o uniwersytetach katolickich "Ex corde Ecclesiae" papieża Jana Pawła II z 15.08.1990, AAS 82(1990), s. 1475-1509. Najważniejsze uregulowania dotyczące uniwersytetów kościelnych zostały umieszczone w rozdziale III tej samej księgi zatytułowanym: „Uniwersytety i wydziały kościelne" oraz w Konstytucji Apostolskiej o uniwersytetach kościelnych „Veritatis gaudium" papieża Franciszka z 8.12.2017, AAS 82(2019). 
Stolicy Apostolskiej mają znaczenie przede wszystkim w porządku kościelnym (choć mogą mieć też znaczenie na forum państwowym). Natomiast w przypadku uniwersytetów katolickich chodzi przede wszystkim o szerokie kształcenie w różnych dziedzinach ludzkiej wiedzy, chociaż zawsze z uwzględnieniem nauki Kościoła oraz chrześcijańskiej wizji człowieka i świata.

„Katolickość" uniwersytetu nie redukuje się jednak do formalnej afiliacji, do statusu prawnego, chociaż, jak twierdzi Richard J. Neuchaus, „może dopomóc w utrzymaniu przekonań" ${ }^{37}$. Zatem jaka jest jego specyfika? By odpowiedzieć na to pytanie, należy najpierw ustalić cechy uniwersytetu katolickiego, szkicując, oczywiście, pewien model czy ideał, a nie wnikając w faktyczną realizację tego ideału przez konkretne uniwersytety (to byłoby zadaniem dla socjologa).

\section{Natura uniwersytetu katolickiego}

W wystąpieniach zarówno zwolenników, jak i krytyków katolickości uniwersytetu powtarza się fraza: „uniwersytet katolicki przede wszystkim powinien być uniwersytetem". Fraza ta jest myląca w swej prostocie, sugeruje bowiem, że istnieje jakiś neutralny byt nazywany uniwersytetem, do którego - niczym posypkę do kawy - można dokooptować katolickość. Rację ma R.J. Neuhaus, twierdząc, że

Nie istnieje coś takiego jak uniwersytet w czystej i prostej postaci. Dlatego mylące jest twierdzenie, że uniwersytet chrześcijański ma «podwójną tożsamość» - jedną $[z]$ racji tego, że jest uniwersytetem, a drugą ze względu na to, że jest chrześcijański ${ }^{38}$.

Uzasadniając swoją tezę pisarz i działacz chrześcijański, przywołał przykład Uniwersytetu Harvarda. Na jego pieczęci, relacjonuje, niegdyś widniało Veritas. Pro Christo et Ecclesia, a obecnie - jedynie Veritas, przy czym - jak komentuje nieco sarkastycznie - „na Harvardzie nie ma oczywiście konsensusu co do tego, czym miałaby być owa prawda, ani nawet

37 R.J. Neuhaus, Jedenaście tez o uniwersytecie chrześcijańskim, tłum. D. Chabrajska, Ethos 2009, z. 1/2 (85/86), s. 22.

38 Tamże, s. 21. 
konsensusu w kwestii tego, czy coś takiego jak prawda w ogóle istnieje"39. I dodaje, iż przez ten czyn

Harvard nie stał się jednak „bardziej” uniwersytetem; stał się natomiast uniwersytetem innego typu. Uniwersytet świecki nie jest uniwersytetem w czystej i prostej postaci, jest on po prostu uniwersytetem świeckim. Słowo „świecki" nie jest bowiem synonimem słowa „neutralny" [...]. Uniwersytet chrześcijański nie ma zatem tożsamości podwójnej, lecz ma wyraźną tożsamość - tożsamość opartą na określeniu tego, jakim uniwersytetem pragnie byćc ${ }^{40}$.

Krótko mówiąc - uniwersytet jest zawsze jakiś: świecki, katolicki, protestancki, muzułmański... Porzucając jedną tożsamość, nie staje się uniwersytetem, ale przekształca się $\mathrm{w}$ uniwersytet innego typu. Pozostawmy na boku zarówno analizy, jakie czynniki wyznaczają tożsamość uniwersytetu określonego typu, jak i pytanie o czynniki odróżniające uniwersytety od innych instytucji społecznych. Zapytajmy natomiast o elementy konstytuujące tożsamość uniwersytetu katolickiego.

Dobrym przewodnikiem $\mathrm{w}$ poszukiwaniu odpowiedzi na to pytanie jest Konstytucja Apostolska Ojca Świętego Jana Pawła II o uniwersytetach katolickich "Ex corde Ecclesiae" z 1990 r. Jan Paweł II był akademikiem i stąd jego przemyślenia mają ogromną wagę. Dokument ten rozpoczyna się następująco:

Narodzony z serca Kościoła, uniwersytet katolicki stanowi część tradycji sięgającej samych początków instytucji uniwersytetu i jawi się niezmiennie jako jedyny w swoim rodzaju ośrodek twórczej pracy i promieniowania wiedzy, służący dobru ludzkości. Wypełniając swe powołanie, Universitas magistrorum et scholarium oddaje się badaniom naukowym oraz nauczaniu i formacji studentów, którzy z własnej woli towarzyszą swym nauczycielom, złączeni $\mathrm{z}$ nimi tą samą miłością wiedzy ${ }^{41}$.

Pisząc powyższe słowa Jan Paweł II, odwołał się do listu papieża Aleksandra IV skierowanego do Uniwersytetu Paryskiego dnia 14 kwietnia 1255 r. Już w powyższym cytacie odnajdziemy wstępną

39 Tamże, s. 22.

40 Tamże.

41 Konstytucja Apostolska Ojca Świętego Jana Pawła II o uniwersytetach katolickich „Ex corde Ecclesiae", s. 1, http://www.opoka.org.pl/biblioteka/W/WP/jan_pawel_ii/konstytucje /o_uniwersytetach_15081990.html [dostęp: 1.08.2017 r.], dalej: Jan Paweł II, Ex corde Ecclesiae. 
charakterystykę uniwersytetu katolickiego i jego tożsamości: jest to ośrodek pracy twórczej, ale też ośrodek przekazywania wiedzy i to nie tylko studentom, ale też światu pozaakademickiemu; służy dobru ludzkości. Termin „promieniowanie” jest tu synonimem rozpowszechniania, odziaływania czy inspirowania. Celami konstytuującymi uniwersytet są badania naukowe, nauczanie i formacja studentów; studenci i wykładowcy tworzą wspólnotę, której podstawą jest miłość do wiedzy. Wszystkie te określenia papież doprecyzowuje $\mathrm{w}$ dalszych częściach dokumentu. Wskazuje przy tym, iż uniwersytet katolicki charakteryzuje się: 1) chrześcijańską inspiracją, będącą udziałem nie tylko jednostek, ale całej uniwersyteckiej wspólnoty jako takiej; 2) nieustanną refleksją, podejmowaną w świetle wiary katolickiej nad coraz bogatszym dziedzictwem ludzkiej wiedzy, które uniwersytet stara się powiększać poprzez własne badania naukowe; 3) wiernością wobec chrześcijańskiego orędzia, takiego, jakim przedstawia je Kościół; 4) instytucjonalnym zaangażowaniem w służbę ludowi Bożemu i rodzinie ludzkiej, podążającym ku transcendentnemu celowi, który nadaje sens życiu ${ }^{42}$.

Kluczowym terminem jest tu oczywiście „wiedza”; jest ona potrzebna do rozumienia świata; a rozumienie wymaga poznania prawdziwego, gdzie prawda to adequatio intellectus et rei. Papież pisze: „Uniwersytet katolicki ma zaszczytny obowiązek poświęcać się całkowicie działaniu na rzecz prawdy"43. Powtórzył tę ideę mocno w przemówieniu na dziedzińcu KUL dnia 9 czerwca 1987 r.: „Uniwersytecie! Alma Mater! [...] Służ Prawdzie! Jeśli służysz Prawdzie - służysz Wolności. Wyzwalaniu człowieka i Narodu. Służysz Życiu!"44. Uniwersyteckie „służenie prawdzie” domaga się doprecyzowania. W pewnym banalnym sensie materiałoznawstwo budowlane czy wzornictwo przemysłowe służą prawdzie, choćby dlatego, że swe nowe substancje czy design tworzą w oparciu o prawdziwe tezy dotyczące natury świata. Nie o taki sens służenia prawdzie jednakże tu chodzi. Jan Paweł II wskazuje wyraźnie, że chodzi o służenie pełnej prawdzie: „Nie rezygnując bynajmniej ze zdobywania pożytecznej wiedzy, uniwersytet katolicki wyróżnia się wolnością poszukiwania całej prawdy

42 Jan Paweł II, Ex corde Ecclesiae, s. 12.

43 Tamże, s. 4.

44 Jan Paweł II, Przemówienie Ojca Świętego do społeczności Katolickiego Uniwersytetu Lubelskiego, http://www.kul.pl/wizyta-ojca-swietego-jana-pawla-ii-w-katolickim-uniwersytecie-lubelskim-9-vi-1987-r,art_43635.html [dostęp: 1.08.2017 r.]. 
o naturze, o człowieku i o Bogu"45. Na czym miałby polegać ideał pełnej prawdy? Pełne rozumienie zjawiska - twierdzi A. MacIntyre - to nie tylko znalezienie odpowiedzi na pytania stawiane w poszczególnych dyscyplinach, ale i „umieszczenie [zjawiska] w kontekście relacji określających jego miejsce $w$ porządku rzeczy" ${ }^{\prime 4}$. Owo pełne rozumienie rzeczy i zjawisk wymaga, by stawiać pytania nie tylko o to, jaka jest rzeczywistość, ale dlaczego jest taka, jaka jest. Poszukiwanie pełnego rozumienia sprawia, że struktura i funkcja badań jest ostatecznie wyznaczona przez badany przedmiot, a nie przez zainteresowania, chęci czy potrzeby wspólnoty poszukujących prawdy lub społeczeństwa, w którym ta wspólnota funkcjonuje. Nie jest więc przypadkiem, że uniwersytet katolicki powinien/ musi mieć nie tylko teologię, ale i filozofię, która stawia ostateczne pytania o istnienie i naturę świata, ale też integruje rozmaite dyscypliny i pokazuje ich granice poznawcze ${ }^{47}$. Papież podkreśla:

Integracja wiedzy jest procesem, który należy nieustannie, udoskonalać. Zadanie to staje się dziś coraz trudniejsze na skutek rozwoju nauki oraz podziału poszczególnych dyscyplin akademickich na coraz węższe specjalizacje. Uniwersytet jednak a szczególnie uniwersytet katolicki „winien być żywą jednością" instytucji oddających się poszukiwaniu prawdy. [...] Należy zatem popierać dążenie do syntezy wyższego rzędu, która jedynie jest w stanie zaspokoić owo pragnienie prawdy wpisane głęboko w serce człowieka ${ }^{48}$.

Wiedza - jako prawdziwe rozumienie świata i siebie w nim - jest dobrem dla człowieka. Należy więc ją zdobywać i uczyć, jak się posługiwać dla dobra jednostek i społeczności. Papież przypomina: ponieważ wiedza winna służyć osobie ludzkiej, badania naukowe prowadzone na uniwersytecie katolickim muszą zawsze brać pod uwagę implikacje etyczne i moralne zarówno stosowanych metod, jak i dokonywanych odkryć. Wrażliwość etyczna potrzebna jest we wszelkiego rodzaju badaniach,

45 Jan Paweł II, Ex corde Ecclesiae, s. 4.

46 A. MacIntyre, Katolickie uniwersytety. Niebezpieczeństwa, nadzieje, wybory, tłum. A. Głąb, Znak 2005, nr 11 (606), s. 18-41.

${ }^{47} \mathrm{~W}$ tej kwestii zob. np. A. MacIntyre, Bóg, filozofia, uniwersytety. Wybrane zagadnienia z historii katolickiej tradycji filozoficznej, tłum. A. Łagodzka, Warszawa 2013; W. Stróżewski, O idei uniwersytetu, w: tenże, W kręgu wartości, Kraków 1992, s. 7-26; J. Haldane, The Future of the University: Philosophy, Education and the Catholic Tradition, American Catholic Philosophical Quarterly 2013, t. 87, nr 4, s. 731-749.

48 Jan Paweł II, Ex corde Ecclesiae, s. 16. 
szczególnie jednak w badaniach naukowych i w poszukiwaniu nowych technologii.

Istotne jest byśmy uświadomili sobie pierwszeństwo etyki przed techniką, prymat osoby wobec rzeczy, wyższość ducha nad materią. Sprawie człowieka służyć będzie jedynie poznanie zespolone z sumieniem. Ludzie nauki, jeśli mają naprawdę pomóc ludzkości, muszą zachować świadomość transcendencji człowieka wobec świata i Boga wobec człowieka ${ }^{49}$.

Na uniwersytecie katolickim etyka, w tym etyka badań naukowych, jest wobec tego koniecznym elementem nauczania.

\section{Misja i funkcje uniwersytetu katolickiego}

Z pewnością Jan Paweł II dał pozytywną odpowiedź na pytanie o misję uniwersytetu katolickiego we współczesnym świecie. Pisze:

W dzisiejszym świecie, charakteryzującym się tak gwałtownym postępem nauki i techniki, zadania uniwersytetu katolickiego stają się coraz ważniejsze i pilniejsze. Odkrycia naukowe i techniczne prowadzą bowiem z jednej strony do ogromnego rozwoju gospodarki i przemysłu, z drugiej jednak stwarzają nieuniknioną konieczność jednoczesnego poszukiwania sensu, które ma zagwarantować, że nowe odkrycia będą służyć prawdziwemu dobru jednostek oraz społeczeństwa ludzkiego jako całości. Choć takie poszukiwanie sensu jest powinnością każdego uniwersytetu, uniwersytet katolicki wezwany jest w sposób szczególny do podjęcia tego zadania: jego chrześcijańska inspiracja pozwala mu uwzględniać $\mathrm{w}$ badaniach naukowych także wymiar moralny, duchowy i religijny oraz oceniać zdobycze nauki i techniki z punktu widzenia integralnego dobra osoby ludzkiej ${ }^{50}$.

Już w tym cytacie papież wskazuje na wyróżnioną rolę uniwersytetu katolickiego: odwołując się do koncepcji osoby ludzkiej i jej ostatecznego celu: jedności z Bogiem, ma obowiązek pytać - i poszukiwać uzasadnionej odpowiedzi - o to, czy kierunek rozwoju naukowego, technicznego, a ostatecznie kierunek rozwoju kulturowego służy dobru człowieka. „Istnieje tylko jedna kultura - twierdzi papież - kultura człowieka, tworzona

\footnotetext{
49 Tamże, s. 18.

50 Tamże, s. 7.
} 
przez człowieka i dla człowieka" 51 . Nie chodzi bynajmniej o ujednolicenie, ale o ocenę, czy proponowane zmiany służą rozwojowi człowieczeństwa w człowieku. To, co Stanisław Kamiński powiedział o filozofii ${ }^{52}$, można mutatis mutandis - powiedzieć więc o uniwersytecie katolickim: ma on stanowić samoświadomość kultury i w tym sensie pełnić rolę „moralnego eksperta". Uniwersytet katolicki, który wyrzeka się tej roli, podważa swoją katolickość.

Druga istotna funkcja zarysowuje się, gdy uwzględnimy fakt ekonomizacji i urynkowienia relacji międzyludzkich. Uniwersytet katolicki stawia alternatywną propozycję: wspólnotowość i przez to jest pewnym wzorcem kulturowym. Przekształcanie uniwersytetu w rodzaj korporacji zagraża jego katolickości w tym sensie, że przestaje być uniwersytetem katolickim, a staje się uniwersytetem innego rodzaju, gdyż - jak to już wyżej zaznaczono - nie ma uniwersytetu „po prostu”.

Kolejna funkcja ujawni się, gdy przyjmiemy, iż racjonalne uzasadnienie oceny - a to jest wymagane od ocen formułowanych $w$ ramach uniwersytetu - wymaga odwołania się do obiektywnych wartości, a nie do subiektywnych emocji.

Uniwersytet katolicki - pisze R.J. Neuhaus - służy wielkiemu dobru jakim jest pluralizm. Nie jest jednak odbiciem fałszywego pluralizmu, który charakteryzuje kulturę udającą, że najgłębsze różnice nie mają żadnego znaczenia, ale poprzez więź opartą na wzajemnym szacunku podejmuje debatę o różnicach, które mają znaczenia zasadnicze ${ }^{53}$.

W zglobalizowanym świecie uniwersytet katolicki staje się przez to miejscem dialogu o najistotniejszych aspektach człowieczeństwa i obrońcą pluralizmu kultur w imię prawdy o człowieku. To ostatnie zastrzeżenie pokazuje, że pluralizm nie prowadzi do kompromisu i relatywizmu, jeśli respektowana jest prawda o tym, co służy dobru człowieka (trudno sobie wyobrazić, by ktoś obecnie potępił Brytyjczyków za zakazywanie w swych indyjskich koloniach palenia żywcem wdów, choć negatywnie oceniamy kolonizację). Uniwersytet katolicki może zaś prowadzić ową

51 Tamże, s. 4.

52 S. Kamiński, O naturze filozofii, w: Jak filozofować? Studia z metodologii filozofii klasycznej, red. T. Szubka, Lublin 1989, s. 45; zob. także A. Lekka-Kowalik, O dostojeństwie uniwersytetu - raz jeszcze, Ethos 2006, z. 3 (75), s. 166.

53 R.J. Neuhaus, Jedenaście tez o uniwersytecie..., s. 22. 
debatę, ponieważ jest „otwarty na całość ludzkiego doświadczenia, zawsze gotów do dialogu i nauczenia się czegoś od każdej kultury"54.

W świecie, w którym głosi się pogląd, iż „każdy ma własną prawdę”, uniwersytet katolicki staje się obrońcą prawdy - a przez to człowieka, ponieważ swe badania naukowe, kształcenie i formację ludzi uniwersytetu opiera na przekonaniu, że prawda jest człowiekowi dostępna; że człowiek nie jest zdany na intelektualne mody, chwilowe hipotezy czy jedynie "prawdy operacyjne" pozwalające manipulować rzeczami.

W naszej epoce - pisze Papież - istnieje bowiem pilna potrzeba takiej właśnie bezinteresownej służby, polegającej na głoszeniu sensu prawdy, tej fundamentalnej wartości, bez której nie może istnieć wolność, sprawiedliwość i godność człowieka ${ }^{55}$.

Więcej, uniwersytet katolicki staje się obrońcą ideału pełnej prawdy, który a priori nie wyklucza żadnego aspektu ${ }^{56}$. Jego zadaniem jest

egzystencjalne jednoczenie $\mathrm{w}$ pracy intelektualnej dwóch porządków rzeczywistości, które nazbyt często są sobie przeciwstawiane, jak gdyby były wzajemnie sprzeczne: porządki te to $\mathrm{z}$ jednej strony poszukiwanie prawdy, a z drugiej pewność, że zna się już źródło prawdy ${ }^{57}$.

Nie zagraża to bynajmniej ani wolności badań naukowych, ani autonomiczności uniwersytetu katolickiego, choć jest to temat na inny artykuł. Umożliwia natomiast stawiania pytań, których wyrzekły się - czy powoli wyrzekają - uniwersytety innego typu, takich jak pytanie o to, kim jest człowiek w swej istocie, jaki jest sens ludzkiego życia, co jest podstawą jedności nauk, jakie wartości są uniwersalne itp.

Jeśli przyjąć, że stawianie takich ostatecznościowych pytań, poszukiwanie na nie racjonalnie uzasadnionych odpowiedzi jest znamieniem akademickości, to uniwersytet katolicki okazuje się - czy raczej powinien być - „przetrwalnikiem” akademickości. Z pewnością sądzi tak A. MacIntyre. „Z katolickiego punktu widzenia - pisze MacIntyre - współczesny uniwersytet świecki jest pomyłką nie dlatego, że nie jest katolicki. Jest

54 Jan Paweł II, Ex corde Ecclesiae, s. 43.

55 Jan Paweł II, Ex corde Ecclesiae, s. 4.

56 Zob. P. Gutowski, Katolickie uniwersytety a ideat petnej prawdy, Znak 2005, z. 11 (606), s. $43-57$.

57 Jan Paweł II, Ex corde Ecclesiae, s. 1. 
pomyłką w takim zakresie, $\mathrm{w}$ jakim nie jest uniwersytetem" ${ }^{58}$. Jest z pewnością ziarno prawdy w tej tezie. W jakimś zakresie Hollywood University of Beauty \& Fashion zapewne służy prawdzie, ale jest to inny rodzaj służby, niż ten, którego oczekiwano od średniowiecznych akademików i do którego wzywał Jan Paweł II na dziedzińcu KUL. Broniąc ideału pełnej prawdy, uniwersytet katolicki jest wciąż uniwersytetem, a nie „multiwersytetem", który redukuje się do listy uprawianych dyscyplin, bez pytań o ich wzajemne związki oraz bez próby powiązania ich wyników.

\section{Zakończenie}

Nie roszczę sobie pretensji do wyliczenia wszystkich ról, jakie we współczesnym świecie ma do spełnienia uniwersytet katolicki. Sądzę natomiast, że powyższe rozważania pozwalają wyciągnąć następujący wniosek: uniwersytet, narodzony ex corde Ecclesiae niemal tysiąc lat temu, któremu w toku rozwoju dziejów dodano przymiotnik „,katolicki”, nie jest historycznym przeżytkiem, skansenem czy utopią. Stanowi żywotny element kształtowania kultury godnej człowieka. Jest obrońcą prawdy, rozumu, godności człowieka i jego transcendentnego przeznaczenia. Dobrze, że są i że przynajmniej niektóre starają się wypełnić misję uniwersytetu katolickiego. Natomiast uniwersytety katolickie, które rezygnują z modelu zarysowanego przez Jana Pawła II, nie stają się bardziej uniwersytetami, ale stają się uniwersytetami innego typu. Zjawisko to jest z pewnością dostrzegalne, a zdaniem R.J. Neuhausa jest ono spowodowane "ambicją naśladowania innych typów uniwersytetu, które fałszywie utrzymują, że są uniwersytetami w czystej i prostej postaci" ${ }^{59}$. Oparcie zaś działania uniwersytetu i jego reformowania na fałszywej przesłance, z pewnością nie jest służeniem prawdzie.

58 A. MacIntyre, The End of Education. The Fragmentation of the American University [online], Commonweal Magazine, October 16, 2006, https://www.commonwealmagazine. org/end-education [dostęp: 22.01.2020 r.]; zob. także tenże, Bóg, filozofia, uniwersytety..., szczególnie rozdz. 1-4, 19.

59 R.J. Neuhaus, Jedenaście tez o uniwersytecie..., s. 22. 


\section{Bibliografia}

Barnard H.C., Education and French Revolution, Cambridge 1969.

Baszkiewicz J., Młodość uniwersytetów, Warszawa 1997.

Bauman Z., Etyka ponowoczesna, Warszawa 2012.

Beck U., What Is Globalization?, Cambridge 2000.

Codex Iuris Canonici. Kodeks Prawa Kanonicznego. Komentarz, red. P. Majer, Kraków 2011.

Dawson C., Religia i powstanie kultury zachodniej, tłum. S. Ławicki, Warszawa 1959.

Dylus A., Globalizacja. Refleksje etyczne, Wrocław 2005.

Eliot T.S., Chóry z „Opoki”, tłum. M. Sprusiński, Więź 1976, z. 12 (224).

Fuller S., On Commodification and the Progress of Knowledge in Society. A Defence, Spontaneous Generations. A Journal for the History and Philosophy of Science 2013, t. 7 , nr 1 .

Gałkowski J.W., D. Stanny, Globalizacja w nauczaniu Jana Pawła II, Ethos 2011, z. 4 (96).

Gilarek K., Państwo narodowe a globalizacja - dynamika powstawania nowego ładu, Toruń 2004.

Grocholewski Z., Rola uniwersytetów katolickich na terenach wyniszczonych przez komunizm, Ethos 2009, z. 1/2 (85/86).

Gutowski P., Katolickie uniwersytety a ideał petnej prawdy, Znak 2005, z. 11 (606).

Haldane J., The Future of the University: Philosophy, Education and the Catholic Tradition, American Catholic Philosophical Quarterly 2013, t. 87, nr 4.

Hammerstein N., Relations with Authority, w: A History of the University in Europe, t. 2. Universities in Early Modern Europe (1500-1800), red. H. de Ridder-Symoens, Cambridge 1997.

Haskins Ch.H., The Renaissance of the Twelfth Century, Cambridge 1971.

Hastings R., The Universities of Europe in the Middle Ages, t. 1-2, Cambridge 2010.

Jan Paweł II, O powołaniu uniwersytetu katolickiego. Przemówienie na Uniwersytecie Katolickim Louvain-la-Neuve, 21 maja 1985 r., w: Jan Paweł II, Wiara i kultura: dokumenty, przemówienia, homilie, wybór tekstów i oprac. red. M. Radwan, T. Gorzkula, K. Cywińska, Rzym-Lublin 1988.

Jońca M., s .v. Universitas, w: Leksykon tradycji rzymskiego prawa prywatnego. Podstawowe pojęcia, red. A. Dębiński, M. Jońca, Warszawa 2016.

Kamiński S., Nauka i Metoda. Pojęcie nauki i klasyfikacja nauk, red. A. Bronk, Lublin 1992.

Kamiński S., O naturze filozofii, w: Jak filozofować? Studia z metodologii filozofii klasycznej, red. T. Szubka, Lublin 1989.

Kempny M., s.v. Globalizacja, w: Encyklopedia socjologii, t. 1, red. Z. Bokszański i in., Warszawa 1998.

Kunowski S., Rola uniwersytetów katolickich w historii nauki i oświaty, Zeszyty Naukowe KUL 1968, t. 11, z. 3/4. 
Lekka-Kowalik A., Komodytyzacja prawdy - komodytyzacja nauki - komodytyzacja człowieka. Chrześcijańska odpowiedź, w: Ekonomia a chrześcijaństwo. Świat biznesu przez pryzmat encyklikśw. Jana Pawła II Centesimus annus i Laborem exercens, red. A. Lekka-Kowalik, Warszawa 2017.

Lekka-Kowalik A., Nauka i Dobro człowieka [online], serwis internetowy Sapiencjokracja - gdzie rządzi mądrość, http://sapiencjokracja.pl/nauka-i-dobro-czlowieka/ [dostęp: 22.01.2020 r.].

Lekka- Kowalik A., O dostojeństwie uniwersytetu - raz jeszcze, Ethos 2006, z. 3 (75).

Lekka-Kowalik A., Uniwersytet na rynku ustug edukacyjnych - szansa czy klęska?, Ethos 2009, z. 1/2 (85/86).

MacIntyre A., Bóg, filozofia, uniwersytety. Wybrane zagadnienia z historii katolickiej tradycji filozoficznej, tłum. A. Łagodzka, Warszawa 2013.

MacIntyre A., The End of Education. The Fragmentation of the American University [online], Commonweal Magazine, October 16, 2006, https://www.commonwealmagazine.org/end-education [dostęp: 28.05.2020 r.].

MacIntyre A., Katolickie uniwersytety. Niebezpieczeństwa, nadzieje, wybory, tłum. A. Głąb, Znak 2005, nr 11 (606).

Márai S., Dziennik (fragmenty), tłum. i oprac. T. Worowska, Warszawa 2008.

Mazurkiewicz P., Uniwersytet „z przymiotnikiem”, Znak 2005, nr 11 (606).

Mezei B.M., Kryzys uniwersytetu. O roli katolickich instytucji kształcenia wyższego, tłum. D. Chabrajska, Ethos 2009, z. 1/2 (85/86).

Misztal H., Uniwersytet katolicki w doktrynie Kościoła i prawie kanonicznym, w: Ius et lex. Księga jubileuszowa ku czci Profesora Adama Strzembosza, red. A. Dębiński, A. Grześkowiak, K. Wiak, Lublin 2002.

Neuhaus R.J., Jedenaście tez o uniwersytecie chrześcijańskim, tłum. D. Chabrajska, Ethos 2009, z. 1/2 (85/86).

Nowak P., Hodowanie troglodytów, Warszawa 2014.

Ortega y Gasset J., Bunt mas, tłum. P. Niklewicz, Zakrzewo 2016.

Pedersen O., The First Universities. Studium Generale and the Origins of University Education in Europe, Cambridge 2000.

Rait R.S., Life in the Medieval University, Cambridge 1912.

Rashdall H., The Universities of Europe in the Middle Ages, Oxford 1895.

Reinalda B., E. Kulesza, The Bologna Process. Harmonizing Europe's Higher Education: Including the Essential Original Texts, Leverkusen-Opladen 2006.

Sakowicz E.K., Uniwersytet katolicki. Teksty - bibliografia - dokumenty, Lublin 2012.

Sawicki S., O uniwersytecie katolickim - dziś. Rozmowa z prof. Stefanem Sawickim, wieloletnim prorektorem KUL, Ethos 2009, z. 1/2 (85/86).

Scott J.C., The Mission of the University: Medieval to Postmodern Transformations, The Journal of Higher Education 2006, t. 77, nr 1.

Scruton R., Koniec uniwersytetu, tłum. D. Chabrajska, Ethos 2015, z. 1 (109).

Sondel J., Słownik łacińsko-polski dla prawników i historyków, Kraków 2005. 
Sondel J., Zawsze wierny. Uniwersytet Jagielloński a Kościót rzymskokatolicki, Kraków 2006. Stróżewski W., O idei uniwersytetu, w: W. Stróżewski, W kręgu wartości, Kraków 1992. Swieżawski S., Kultura umysłowa wieków średnich, Lublin 1949.

Sztompka P., Socjologia zmian społecznych, tłum. J. Konieczny, Kraków 2005.

Verger J., The Birth of the Universities, w: A History of the University in Europe, t. 1. Universities in the Middle Ages, red. H. de Ridder-Symoens, Cambridge 1992.

Weber M., Nauka jako zawód i powołanie, w: M. Weber, Polityka jako zawód i powołanie. Wybór pism, wstęp i oprac. Z. Krasnodębski, tłum. P. Dybel, Warszawa 1998. Węcławski T., Uniwersytet i wyzwania fundamentalne, Znak 2000, nr 2 (537).

Wnuk-Lipiński E., Świat międzyepoki. Globalizacja, demokracja, państwo narodowe, Kraków 2004.

\section{Streszczenie}

Jednym z największych osiągnięć umysłowych czasów, określanych mianem Wieków Średnich, było powstanie uniwersytetów. Uniwersytety, stając się motorem rozwoju cywilizacji, powoływane były przez Kościołów i były przejawem wysokiego poziomu kultury europejskiej i chrześcijańskiej. Z czasem jednak doszły do głosu tendencje sekularystyczne i upaństwawiające. Stąd też, w XIX w. z inicjatywy papieża Leona XIII tworzono lub reaktywowano uniwersytety, które w swojej nazwie zyskały przydomek katolickie. Celem artykułu jest przedstawienie kluczowych trendów współczesności - takich jak globalizacja, pluralizm wartości, urynkowienie oraz budowanie społeczeństwa wiedzy - mających wpływ na funkcjonowanie uniwersytetów, w tym uczelni katolickich. Niniejszy artykuł omawia także status prawnego, ale przede wszystkim naturę oraz misję katolickich uniwersytetów.

Słowa kluczowe: uniwersytet katolicki; uniwersytet, natura uniwersytetu, misja uniwersytetu

\section{EX CORDE ECCLESIAE ON THE NATURE AND MISSION OF THE CATHOLIC UNIVERSITY}

\section{Summary}

One of the greatest intellectual achievements of the times referred to as the Middle Ages was the emergence of universities. Serving as catalysts for the development of the civilization, universities were established by the Church and were a manifestation of a high level of the European and Christian culture. However, 
with the passage of time, secularist and nationalizing tendencies in this area became more pronounced. Therefore, in the $19^{\text {th }}$ century, through the initiative of Pope Leo XIII, the name "catholic" was added to the newly established or reactivated universities. The aim of the article is to present the key contemporary trends, such as globalization, pluralism of values, free-market principles and the building of a knowledge-based society, which all have a significant impact on the functioning of universities, including the catholic ones. The current article discusses primarily the nature and mission of catholic universities, as well as their legal status.

Key words: catholic universities, university, nature of the university, mission of the university

\section{EX CORDE ECCLESIAE. О ПРИРОДЕ И МИССИИ КАТОЛИЧЕСКОГО УНИВЕРСИТЕТА}

\section{Резюме}

Одним из величайших интеллектуальных достижений Средневековья было создание университетов. Университеты, становясь двигателем развития цивилизации, были созданы Церквами и являлись проявлением высокого уровня европейской и христианской культуры. Однако со временем возникли секулярные и национализирующие тенденции. Следовательно, в XIX веке по инициативе папы Льва XIII были созданы или возобновлены университеты, которые в своем названии получили компонент «католический». Целью настоящей статьи является представление основных тенденций современности, таких как: глобализация, плюрализм ценностей, рыночное развитие и построение общества знания, влияющих на функционирование университетов, в том числе католических высших учебных заведений. В статье обсуждается также правовой статус, но прежде всего характер и миссия католических университетов.

Ключевые слова: католический университет, университет, природа университета, миссия университета 
